\title{
PENGARUH PEMBERIAN MIKRO ORGANISME LOKAL (MOL) NASI DAN HORMON TANAMAN UNGGUL TERHADAP PERTUMBUHAN DAN PRODUKSI TANAMAN CABAI (Capsicum Annum L.)
}

\section{Influence of giving Local Microorganism of Rice and Superior Plant Hormone on Growth and Yield of Chilli ((Capsicum Annum L.)}

\author{
Sarmi Julita, Hercules Gultom dan Mardaleni \\ Fakultas Pertanian Universitas Islam Riau, Jl. Kaharuddin Nasution 113, Pekanbaru 28284 Riau \\ Telp: 0761-72126 ext. 123, Fax: 0761-674681 \\ [Diterima Oktober 2013, Disetujui Desember 2013]
}

\begin{abstract}
The objective of this research was to examine the effect of giving Rice MOL and superior plant hormone on growth and yield of Chilli. The experiment was arranged using the completely randomized design with two factors. The first factor was rice MOL (M), namely M0 (without rice MOL), M1 (50 cc/l water), M2 (100 cc/l water), and M3 (150 cc/l water).The second factor was application of superior plant hormone $(\mathrm{H})$, consisting of four factor, namely $\mathrm{H} 0$ (without hormone), H1 1 cc/l water), H2 (2 cc/l water), and H3 (3 cc/l water). The parameters observed were plant height, flowering age, the first harvest age, fruit weight per plant, fruit weight per plot, and number of remaining fruit. Data were analyzed using statistical technique and continuing test of BNJ at 5\% confident level. The results showed that the interaction of giving rice MOL and hormone had a significant effect on flowering age and harvest age with the best treatment $\mathrm{M} 2 \mathrm{H} 2$ with 56.67 days and $\mathrm{M} 2 \mathrm{H} 2$ with 112.67 days, respectively. The rice MOL alone gave a significant effect on flowering age, the first harvest age, econmic fruit weight per plant, and economic fruit weight per plot with the best treatment was M2. The superior plant hormone alone affected significantly plant height, flowering age, the first harvested age, economic fruit weight per plant, economic fruit weight per plot, and number of remaining uneconomic fruit per plant with the best treatment of $\mathrm{H} 2$.
\end{abstract}

Keywords: Chilli, Rice MOL, Superior plant hormone, growth, yield.

\begin{abstract}
ABSTRAK
Tujuan penelitian adalah untuk mengetahui pengaruh pemberian MOL Nasi dan hormon tanaman unggul terhadap pertumbuhan dan produksi tanaman cabai. Penelitian ini menggunakan Rancang Acak Lengkap (RAL) yang terdiri dari dua faktor. Faktor pertama yaitu MOL nasi (M) yaitu M0 (tanpa pemberian MOL nasi), M1 (50 cc/l air), M2 (100 cc/l air) dan M3 (150 cc/l air). Faktor kedua yaitu pemberian hormon tanaman unggul $(\mathrm{H})$ yang terdiri dari 4 taraf yaitu H0 (tanpa pemberian hormon tanaman unggul), H1 (1 cc/l air), H2 (2 cc/l air) dan H3 (3 cc/l air). Param eter yang diamati yaitu Tinggi tanaman (cm), Umur berbunga (hari), Umur panen pertama (hari), Berat buah per tanaman yang ekonomis (g), Berat buah per plot yang ekonomis (g) dan Jumlah buah sisa per tanaman yang tidak ekonomis (buah). Data dianalisis secara statistik dan diuji lanjut BNJ pada taraf 5\%. Hasil penelitian menunjukkan bahwa interaksi pemberian MOL nasi dan hormon tanaman unggul berpengaruh nyata terhadap umur berbunga, dimana perlakuan terbaik yaitu $\mathrm{M} 2 \mathrm{H} 2$ dengan umur berbunga 56,67 hari dan umur panen pertama dimana perlakuan terbaik M2H2 dengan umur panen pertama 112,67 hari. Perlakuan MOL nasi berpengaruh nyata terhadap umur berbunga, umur panen pertama, berat buah per tanaman yang ekonomis dan berat buah per plot yang ekonomis pada perlakuan terbaik M2. Perlakuan hormon tanaman unggul berpengaruh nyata terhadap tinggi tanaman, umur berbunga, umur panen pertama, berat buah per tanaman yang ekonomis, berat buah per plot yang ekonomis dan jumlah buah sisa per tanaman yang tidak ekonomis pada perlakuan terbaik $\mathrm{H} 2$.
\end{abstract}

Kata kunci: Cabai, MOL nasi, Hormone tanaman unggul, Pertumbuhan, Produksi. 


\section{PENDAHULUAN}

Tanaman cabai (Capsicum annum. L) merupakan salah satu tanaman hortikultura dari kelompok sayur-sayuran yang mendapat pasaran cukup baik akhir-akhir ini. Tanaman ini mendapat perhatian petani karena memiliki nilai ekonomis yang cukup tinggi terutama pada waktu tertentu seperti pada bulan puasa Ramadhan dan pada hari besar keagamaan. Buahnya dikenal sebagai bahan penyedap dan pelengkap berbagai khas masakan Indonesia serta bahan baku industri.

Cabai mempunyai banyak kandungan gizi berupa protein dan vitamin yang berguna bagi tubuh. Kandungan gizi cabai merah segar per $100 \mathrm{~g}$ yaitu Kalori 31,0 kal, Protein 1,0 g, Lemak 0,3 g, Karbohidrat 7,3 g, Kalsium 29,0 g, Fosfor 24,0 mg, Besi 0,5 mg, Vitamin A 470 SI, Vitamin C 18,0 mg, Vitamin B1 0,05 mg, Vitamin B2 0,03 mg, Niasin 0,20 mg, Capsaicin 0,1-1,5\%, Pektin 2,33\%, Pentosan 8,57\% dan Pati 0,8-1,4\% (Agromedia, 2008).

Produksi cabai di Riau pada tahun 2007 adalah 8.137 ton dan pada tahun 2010 produksi menurun menjadi 7.609 ton. Pada tahun 2011 diperkirakan 10.504 ton (Badan Pusat Statistik dan Direktorat Jenderal Hortikultura, 2010). Menurut Zuprianto (2011), Riau ternyata belum bisa memenuhi permintaan masyarakat akan cabai. Luas areal tanaman cabai di Pekanbaru 179 ha dengan produksi 900 ton/tahun atau perharinya 2,46 ton. Sementara kebutuhan cabai mencapai 4 ton per hari. Akibatnya, Pekanbaru terpaksa mengimpor cabai dari Bukittinggi, Jawa dan Medan.

Salah satu faktor penyebab rendahnya produksi cabai di Riau yaitu rendahnya tingkat kesuburan tanah serta pemeliharaan yang masih belum optimal seperti penggunaan pupuk, pengendalian hama dan penyakit, dan lain-lain.

Salah satu cara mengatasinya yaitu memberdayakan pembuatan MOL dikalangan petani yang dapat digunakan sebagai dekomposer maupun sebagai pupuk organik dilahan pertaniannya sehingga mampu menekan biaya produksi dan meningkatkan kualitas dan kuantitas hasil pertanian. MOL bisa dimanfaatkan sebagai pupuk organik cair (POC) ataupun pupuk hayati yang bisa langsung diaplikasikan pada media tanam. Salah satu jenis MOL yaitu MOL dengan bahan baku nasi sisa atau nasi basi.

Hormon tanaman unggul ini terbuat dari sari tumbuhan alami (herbal) seperti tumbuhtumbuhan sirih, madu, lemak hewan dan beberapa zat lainnya. Manfaat hormon ini yaitu: 1. Daun; mempercepat pertumbuhan daun menjadi lebat, keras, padat, lebar, tebal, berisi dan mengkilap dan tidak mudah rontok, 2. Batang; mempercepat perkembangan batang dalam melakukan pembelahan sel, sehingga cepat besar, kokoh dan berurat, 3. Bunga; mempercepat keluarnya bunga, kuncup disetiap pori pembuahan dan tidak mudah gugur, 4. Buah; mempercepat putik bunga menjadi buah dan buah menjadi lebih padat, besar dan berisi dan beraroma, 5. Akar; mempercepat pertumbuhan akar baru dan kokoh, 6. Tunas; mempercepat keluarnya tunas-tunas dan anakan baru pada setiap pori (Jimmy, 2011).

Tujuan penelitian yaitu untuk mengetahui pengaruh interaksi pemberian MOL nasi dan hormon tanaman unggul terhadap pertumbuhan dan produksi tanaman cabai, untuk mengetahui pengaruh pemberian MOL nasi terhadap pertumbuhan dan produksi tanaman cabai, untuk mengetahui pengaruh pemberian hormon tanaman unggul terhadap pertumbuhan dan produksi tanaman cabai.

\section{METODE PENELITIAN}

Penelitian ini telah dilaksanakan di Kebun Percobaan Fakultas Pertanian Universitas Islam Riau Pekanbaru. Penelitian dilaksanakan selama lima bulan terhitung dari bulan September 2012 sampai dengan bulan Januari 2013.

Bahan yang digunakan dalam penelitian ini adalah benih cabai varietas Lado $F 1$, nasi sisa, gula, air leri, air kelapa, daun bambu yang sudah lapuk, Hormon Tanaman Unggul, pupuk NPK Mutiara 16:16:16, Curacron, Agrimex, dan Dithane M 45.

Alat yang digunakan yaitu cangkul, parang, kardus, polybag ukuran $8 \mathrm{~cm} \times 10 \mathrm{~cm}$, tali raffia, seng, paku, ember, martil, gergaji, literan, meteran, gembor, toples, hand sprayer, pisau karter, pisau karter, timbangan, kamera, alat alat tulis dll.

Penelitian ini menggunakan Rancangan Acak Lengkap (RAL) faktorial yang terdiri dari 2 faktor. Faktor pertama adalah MOL nasi (M) 
yang terdiri dari 4 taraf. Sedangkan faktor kedua yaitu konsentrasi hormon tanaman unggul $(\mathrm{H})$ yang terdiri dari 4 taraf perlakuan, dan didapat 16 kombinasi perlakuan. Faktor M (MOL Nasi), yaitu: M0: Tanpa pemberian MOL Nasi, M1: 50 cc/liter air, M2: 100 cc/liter air, M3: 150 cc/liter air. Faktor H (Hormon Tanaman Unggul), yaitu: H0: Tanpa pemberian hormon, H1: 1 cc/liter air, H2: 2 cc/liter air, H3: 3 cc/liter air. Data dianalisis secara statistik dengan menggunakan analisis sidik ragam (ANOVA). Apabila $F$ hitung lebih besar dari $\mathrm{F}$ tabel, maka dilanjutkan dengan melakukan uji lanjut Beda Nyata Jujur (BNJ) pada taraf 5\%.

Parameter Pengamatan yaitu Tinggi Tanaman (cm), Umur Berbunga (hari), Umur Panen Pertama (hari), Berat Buah Per Tanaman yang Ekonomis (g), Berat Buah Per Plot yang Ekonomis (g), Jumlah Buah Sisa Per Tanaman yang Tidak Ekonomis (buah).

\section{HASIL DAN PEMBAHASAN}

\section{Tinggi Tanaman}

Hasil pengamatan terhadap tinggi tanaman setelah dianalisis sidik ragam menunjukkan bahwa secara interaksi pemberian perlakuan MOL nasi dan hormon tanaman unggul tidak memberikan pengaruh yang nyata terhadap pengamatan tinggi tanaman. Pemberian MOL nasi secara tunggal tidak memberikan pengaruh nyata terhadap pengamatan tinggi tanaman. Pengaruh utama faktor tunggal ditunjukkan pada perlakuan hormon tanaman unggul. Rerata hasil pengamatan terhadap tinggi tanaman dapat dilihat pada Tabel 1 .

Data pada Tabel 2 memperlihatkan bahwa pengaruh utama faktor tunggal hormon tanaman unggul berpengaruh nyata terhadap tinggi tanaman. Perlakuan terbaik yaitu pada H2 (2 cc/l air) dengan tinggi tanaman 96,55 $\mathrm{cm}$. Perlakuan MOL nasi dengan konsentrasi yang telah ditentukan pada penelitian ini, ternyata tidak memberikan pengaruh yang nyata terhadap pengamatan tinggi tanaman. Hal ini bisa terjadi karena MOL nasi bukan tergolong pupuk sebagai penyedia unsur hara melainkan sebagai pupuk organik cair yang lebih banyak mengandung kelompok mikroba. Larutan MOL mengandung unsur bakteri yang sangat berpotensi untuk perombak bahan organik sampah menjadi pupuk kompos.

Hormon tanaman unggul ini memiliki kandungan hara yang komplek yang terdiri dari

Tabel 1. Rerata Tinggi Tanaman Cabai dengan Perlakuan MOL Nasi dan Hormon Tanaman Unggul $(\mathrm{cm})$

\begin{tabular}{|c|c|c|c|c|c|}
\hline \multirow{2}{*}{ Faktor M (cc/l air) } & \multicolumn{4}{|c|}{ Faktor H (cc/l air) } & \multirow{2}{*}{ Rerata } \\
\hline & $\mathrm{H} 0(0)$ & H1 (1) & $\mathrm{H} 2(2)$ & H3 (3) & \\
\hline M0 (0) & 71,17 & 76,33 & 94,67 & 75,50 & 79,42 \\
\hline M1 (50) & 76,08 & 79,25 & 96,58 & 84,75 & 84,17 \\
\hline M2 (100) & 86,83 & 82,83 & 102,13 & 83,25 & 88,76 \\
\hline M3 (150) & 71,92 & 84,42 & 92,83 & 79,30 & 82,12 \\
\hline Rerata & $76,50 \mathrm{~b}$ & $80,71 \mathrm{~b}$ & $96,55 \mathrm{a}$ & $80,70 \mathrm{~b}$ & \\
\hline
\end{tabular}

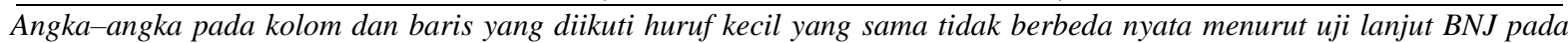
taraf $5 \%$.

Tabel 2. Rerata Umur Berbunga Tanaman Cabai dengan Perlakuan MOL Nasi dan Hormon Tanaman Unggul (hari)

\begin{tabular}{lccccc}
\hline \multirow{2}{*}{$\begin{array}{l}\text { Faktor M (cc/l } \\
\text { air) }\end{array}$} & \multicolumn{4}{c}{ Faktor H (cc/l air) } & \multirow{2}{*}{ Rerata } \\
\cline { 2 - 4 } M0 (0) & $69,33 \mathrm{~d}$ & $62,00 \mathrm{abcd}$ & $59,33 \mathrm{abc}$ & $64,00 \mathrm{abcd}$ & $63,67 \mathrm{~b}$ \\
M1 (50) & $63,33 \mathrm{abcd}$ & $66,33 \mathrm{~cd}$ & $59,00 \mathrm{abc}$ & $60,67 \mathrm{abc}$ & $62,33 \mathrm{ab}$ \\
M2 (100) & $60,00 \mathrm{abc}$ & $59,33 \mathrm{abc}$ & $56,67 \mathrm{a}$ & $64,00 \mathrm{abcd}$ & $60,00 \mathrm{a}$ \\
M3 (150) & $61,67 \mathrm{abc}$ & $65,33 \mathrm{bcd}$ & $58,33 \mathrm{ab}$ & $65,33 \mathrm{bcd}$ & $62,67 \mathrm{ab}$ \\
\hline \multicolumn{1}{c}{ Rerata } & $63,58 \mathrm{~b}$ & $63,25 \mathrm{~b}$ & $58,33 \mathrm{a}$ & $63,50 \mathrm{~b}$ &
\end{tabular}

KK $=6,00 \% \quad$ BNJ M/H $=2,74 \quad$ BNJ MH $=7,49$

Angka-angka pada kolom dan baris yang diikuti huruf kecil yang sama tidak berbeda nyata menurut uji lanjut BNJ pada taraf $5 \%$. 
unsur hara makro dan unsur hara mikro. Dengan kandungan hara yang komplek tersebut, cabai merah terbukti dapat meningkatkan laju pertumbuhan tanaman cabai merah. Hal itu terlihat pada pengamatan tinggi tanaman pada perlakuan $\mathrm{H} 2$ yang berbeda nyata dengan perlakuan yang lain. Pemberian perlakuan $2 \mathrm{cc} / 1$ air menghasilkan rerata tinggi tanaman terbaik karena konsentrasi $2 \mathrm{cc} / \mathrm{l}$ air merupakan konsentrasi anjuran penggunaan untuk tanaman cabai, sesuai dengan hasil anjuran Jimmy (2011) yang menemukan hormon tanaman unggul ini, bahwa konsentrasi yang dianjurkan untuk tanaman cabai yaitu $2 \mathrm{cc} / \mathrm{l}$ air dengan interval 710 hari sekali. Selanjutnya hasil penelitian Ikhsan (2012), juga menunjukkan bahwa pemberian hormon tanaman unggul memberikan hasil pengamatan tinggi tanaman cabai terbaik pada perlakuan $2 \mathrm{cc} / \mathrm{liter}$ air.

\section{Umur Berbunga (hari)}

Hasil pengamatan terhadap umur berbunga setelah dianalisis sidik menunjukkan bahwa perlakuan MOL nasi dan hormon tanaman unggul memberikan pengaruh yang nyata terhadap pengamatan umur berbunga tanaman cabai baik secara interaksi maupun secara tunggal. Rerata hasil pengamatan terhadap umur berbunga dapat dilihat pada Tabel 2.

Data pada Tabel 2 menunjukkan bahwa pemberian perlakuan MOL nasi dan hormon tanaman unggul memberikan pengaruh yang nyata terhadap pengamatan umur berbunga tanaman cabai, baik secara interaksi maupun secara tunggal. Perlakuan M2H2 merupakan perlakuan terbaik dengan pemberian MOL nasi $100 \mathrm{cc} / \mathrm{l}$ air dan hormon tanaman unggul $2 \mathrm{cc} / \mathrm{l}$ air (M2H2) dengan umur berbunga 56,67 hari. Perlakuan M2H2 menjadi perlakuan dengan umur berbunga tercepat. Hal ini disebabkan karena pada kombinasi perlakuan $\mathrm{M} 2 \mathrm{H} 2$, unsur hara yang terdapat pada hormon tanaman unggul serta mikroba yang ada pada MOL nasi mampu memperbaiki sifat fisik tanah sehingga menghasilkan lingkungan yang kondusif bagi pertumbuhan tanaman cabai.

Pemberian MOL nasi secara tunggal memberikan pengaruh yang nyata terhadap pengamatan umur berbunga tanaman cabai. Perlakuan terbaik ditunjukkan pada perlakuan M2 (100 cc/l air) dengan umur berbunga 60 hari. Perlakuan H2 (2 cc/l air) mencapai umur berbunga tercepat dikarenakan hormon tanaman unggul mengandung ZPT golongan auksin dan gibberellin yang berfungsi mempercepat pertumbuhan akar tanaman muda, membantu dalam penyerapan hara dan meningkatkan proses kegiatan fotosintesis, serta dapat memacu pertumbuhan vegetatif dan generatif tanaman sebagai memacu titik tumbuh tanaman.

\section{Umur Panen Pertama}

Hasil pengamatan terhadap umur panen tanaman cabai setelah dianalisis sidik ragam menunjukkan bahwa perlakuan MOL nasi dan hormon tanaman unggul memberikan pengaruh yang nyata terhadap pengamatan umur panen tanaman cabai baik secara interaksi maupun secara tunggal setelah dilakukan uji lanjut Beda Nyata Jujur (BNJ) pada taraf 5\%. Rerata hasil pengamatan terhadap umur panen dapat dilihat pada Tabel 3.

Tabel 3 memperlihatkan bahwa interaksi pemberian MOL nasi dan hormon tanaman unggul memberikan pengaruh nyata terhadap pengamatan umur panen tanaman cabai dimana perlakuan M2H2 (MOL nasi $100 \mathrm{cc} / \mathrm{l}$ air dan hormon tanaman unggul $2 \mathrm{cc} / \mathrm{l}$ air) merupakan perlakuan terbaik dengan umur panen 112,67

Tabel 3. Rerata Umur Panen Tanaman Cabai dengan Perlakuan MOL Nasi dan Hormon Tanaman Unggul (hari)

\begin{tabular}{|c|c|c|c|c|c|}
\hline \multirow{2}{*}{$\begin{array}{c}\text { Faktor M (cc/l } \\
\text { air) }\end{array}$} & \multicolumn{4}{|c|}{ Faktor H (cc/l air) } & \multirow{2}{*}{ Rerata } \\
\hline & H0 (0) & H1 (1) & $\mathrm{H} 2(2)$ & H3 (3) & \\
\hline M0 (0) & $125,33 \mathrm{~d}$ & 118,00 abcd & $117,00 \mathrm{abc}$ & 120,00 abcd & $120,08 \mathrm{~b}$ \\
\hline M1 (50) & $119,33 \mathrm{abcd}$ & $122,33 \mathrm{~cd}$ & $115,00 \mathrm{abc}$ & $116,67 \mathrm{abc}$ & $118,33 \mathrm{ab}$ \\
\hline M2 (100) & $116,00 \mathrm{abc}$ & $115,33 a b c$ & $112,67 \mathrm{a}$ & $120,00 \mathrm{abcd}$ & $116,00 \mathrm{a}$ \\
\hline M3 (150) & $117,67 \mathrm{abcd}$ & $121,33 \mathrm{bcd}$ & $114,33 \mathrm{ab}$ & $121,33 \mathrm{bcd}$ & $118,67 \mathrm{ab}$ \\
\hline Rerata & $119,58 \mathrm{~b}$ & $119,25 \mathrm{~b}$ & $114,75 \mathrm{a}$ & $119,50 \mathrm{~b}$ & \\
\hline $\mathrm{KK}=2,69 \%$ & & $\mathrm{M} / \mathrm{H}=2,90$ & & $\mathrm{MH}=7,92$ & \\
\hline
\end{tabular}


Tabel 4. Rerata Berat Buah Per Tanaman Cabai yang Ekonomis Dengan Perlakuan MOL Nasi dan Hormon Tanaman Unggul (g)

\begin{tabular}{|c|c|c|c|c|c|}
\hline \multirow{2}{*}{$\begin{array}{c}\text { Faktor M (cc/l } \\
\text { air) }\end{array}$} & \multicolumn{4}{|c|}{ Faktor H (cc/l air) } & \multirow{2}{*}{ Rerata } \\
\hline & HO (0) & H1 (1) & $\mathrm{H} 2(2)$ & H3 (3) & \\
\hline M0 (0) & 442,77 & 486,99 & 635,79 & 528,41 & $523,49 \mathrm{~b}$ \\
\hline M1 (50) & 512,70 & 509,33 & 621,95 & 567,25 & $552,81 \mathrm{~b}$ \\
\hline M2 (100) & 590,08 & 648,14 & 816,51 & 551,82 & $651,64 \mathrm{a}$ \\
\hline M3 (150) & 515,24 & 511,53 & 649,05 & 525,46 & $550,32 \mathrm{~b}$ \\
\hline \multirow[t]{2}{*}{ Rerata } & $515,20 \mathrm{~b}$ & $539,00 \mathrm{~b}$ & 680,82 a & $543,23 \mathrm{~b}$ & \\
\hline & &, $98 \%$ & $\mathrm{BNJ}$ & $\mathrm{H}=63,02$ & \\
\hline
\end{tabular}

Tabel 5. Rerata Berat Buah Per Plot Tanaman Cabai yang Ekonomis dengan Perlakuan MOL Nasi dan Hormon Tanaman Unggul (g)

\begin{tabular}{|c|c|c|c|c|c|}
\hline \multirow{2}{*}{$\begin{array}{c}\text { Faktor M (cc/l } \\
\text { air) }\end{array}$} & \multicolumn{4}{|c|}{ Faktor H (cc/l air) } & \multirow{2}{*}{ Rerata } \\
\hline & H0 (0) & H1 (1) & $\mathrm{H} 2(2)$ & H3 (3) & \\
\hline M0 (0) & 1600,41 & 2281,29 & 2676,50 & 2385,63 & $2235,96 \mathrm{~b}$ \\
\hline M1 (50) & 2217,46 & 2603,98 & 3054,45 & 2468,99 & $2586,22 \mathrm{ab}$ \\
\hline M2 (100) & 2446,97 & 2712,56 & 3432,69 & 2773,95 & $2841,54 \mathrm{a}$ \\
\hline M3 (150) & 2094,29 & 2032,80 & 2562,86 & 2368,51 & $2264,61 \mathrm{~b}$ \\
\hline \multirow[t]{2}{*}{ Rerata } & $2089,78 \mathrm{c}$ & $2407,66 \mathrm{bc}$ & $2931,62 \mathrm{a}$ & $2499,27 \mathrm{~b}$ & \\
\hline & \multicolumn{2}{|c|}{$\mathrm{KK}=12,12 \%$} & \multicolumn{2}{|c|}{$\mathrm{BNJ} \mathrm{M} / \mathrm{H}=333,59$} & \\
\hline
\end{tabular}

Angka-angka pada kolom dan baris yang diikuti huruf kecil yang sama tidak berbeda nyata menurut uji lanjut BNJ pada taraf $5 \%$.

hari.

Menurut Purwasasmita (2009), larutan MOL selain mengandung bakteri yang berpotensi sebagai perombak bahan organik, sebagai pengendali hama dan penyakit tanaman juga berperan sebagai perangsang pertumbuhan. Hal ini terbukti setelah diaplikasikan pada tanaman cabai dengan konsentrasi $100 \mathrm{cc} / \mathrm{l}$ air mampu memberikan pengaruh yang nyata terhadap pengamatan umur panen tanaman.

Pemberian MOL nasi secara tunggal berpengaruh terhadap umur panen tanaman cabai. Umur panen tercepat terdapat pada perlakuan M2 (100 cc/l air) yaitu 116,00 hari. Perlakuan hormon tanaman unggul secara tunggal berpengaruh nyata terhadap umur panen tanaman cabai dimana perlakuan H2 (2 cc/l air) dengan umur panen 114,75 hari merupakan perlakuan terbaik.

\section{Berat Buah Per Tanaman yang Ekonomis}

Hasil pengamatan terhadap parameter produksi berat buah per tanaman cabai yang memiliki nilai ekonomis setelah dilakukan analisis sidik ragam menunjukkan bahwa interaksi pemberian MOL nasi dan hormon tanaman unggul tidak memberikan pengaruh nyata. Perlakuan MOL nasi dan pemberian hormon tanaman unggul secara tunggal berpengaruh nyata terhadap pengamatan berat buah per tanaman yang ekonomis setelah dilakukan uji lanjut Beda Nyata Jujur pada taraf 5\% dapat dilihat pada Tabel 4 .

MOL nasi secara tunggal memberikan pengaruh nyata terhadap pengamatan berat buah per tanaman yang ekonomis, dimana perlakuan terbaik yaitu M2 (100 cc/l air) dengan berat buah per tanaman $651,64 \mathrm{~g}$ atau setara dengan 18,10 ton/ ha.

MOL nasi ini bukanlah nutrisi tetapi larutan yang lebih banyak mengandung mikroba yang bisa membantu sebagai dekomposer untuk ketersediaan unsur hara pada tanah agar bisa diserap oleh tanaman. Larutan mikroorganisme juga sering dikatakan sebagai salah satu pupuk hayati. Menurut PT. Singa Langit dalam Soverda dan Hermawati (2009), pupuk hayati merupakan pupuk yang kandungan utamanya adalah makhluk hidup (mikroorganisme) yang menguntungkan bagi pertumbuhan tanaman. 
Hormon tanaman unggul merupakan perpaduan antara pupuk dan zat pengatur tumbuh yang menjadikan tanaman mempunyai daya tahan dan kemampuan tumbuh yang melebihi perkembangan standar. Anonim (2004) Hal ini terutama terlihat pada bunga yang akan muncul dari semua pori-pori pohon, buah akan padat berisi, batang mengalami pemekaran selselnya dan akar berkembang dengan pesat. Hal ini terbukti setelah pengaplikasian pada tanaman cabai, pemberian hormon tanaman unggul memberikan pengaruh yang nyata terhadap pengamatan berat buah per tanaman yang ekonomis dimana $\mathrm{H} 2$ (2 cc/l air) merupakan perlakuan terbaik dengan berat buah $680,82 \mathrm{~g}$ atau setara dengan 18,91 ton/ ha.

\section{Berat Buah Per Plot yang Ekonomis}

Hasil pengamatan terhadap parameter berat buah per plot tanaman cabai yang ekonomis, menunjukkan bahwa secara interaksi pemberian MOL nasi dan hormon tanaman unggul tidak berpengaruh nyata terhadap berat buah per plot. Perlakuan MOL nasi dan hormon tanaman unggul secara tunggal memberikan pengaruh nyata terhadap pengamatan berat buah per plot setelah dilakukan analisis sidik ragam dan uji lanjut Beda Nyata Jujur pada taraf 5\% dapat dilihat pada Tabel 5.

Dari Tabel 5 dapat dilihat bahwa secara interaksi pemberian MOL nasi dan hormon tanaman unggul tidak berpengaruh nyata terhadap produksi per plot tanaman cabai yang ekonomis. Pemberian MOL nasi secara tunggal berpengaruh nyata terhadap berat buah per plot tanaman cabai yang ekonomis, dimana perlakuan terbaik ditunjukkan pada perlakuan M2 (100 cc/l air) dengan jumlah produksi per plot 2841,54 $\mathrm{g}$ atau setara dengan 19,74 ton/ha.

MOL nasi yang diaplikasikan pada tanaman cabai ternyata mampu memberikan pengaruh nyata terhadap berat buah per plot yang ekonomis. MOL nasi yang mengandung mikroba mampu memperbaiki struktur tanah dan memperbaiki aerase tanah menjadi lebih baik sehingga dengan adanya mikroba ini, akar tanaman menjadi lebih mudah mendapatkan unsur hara karena unsur hara menjadi tersedia bagi tanaman.

Pemberian hormon tanaman unggul memberikan pengaruh nyata terhadap pengamatan berat buat per plot tanaman cabai yang ekonomis dimana perlakuan terbaik pada H2 (2 cc/l air) dengan berat buah 2931,62 g atau setara dengan 20,34 ton/ha.

Tingginya produksi berat buah per plot yang ekonomis pada perlakuan $\mathrm{H} 2$ disebabkan karena konsentrasi pemberian hormon tanaman unggul sebanyak $2 \mathrm{cc} / \mathrm{l}$ air ini sudah mampu untuk memenuhi kebutuhan tanaman cabai, tetapi tidak tertutup kemungkinan untuk bisa menghasilkan produksi yang lebih besar karena banyak faktor yang ikut mempengaruhi berat produksi seperti iklim mikro, ketersediaan unsur hara, ketersediaan air serta hama dan penyakit yang ada pada tanaman.

\section{Jumlah Buah Sisa Per Tanaman yang Tidak Ekonomis}

Hasil pengamatan terhadap parameter pengamatan jumlah buah sisa tanaman cabai yang tidak memiliki nilai ekonomis, setelah dilakukan analisis sidik ragam menunjukkan bahwa secara interaksi pemberian perlakuan MOL nasi dan hormon tanaman unggul tidak berpengaruh nyata terhadap pengamatan jumlah buah sisa yang tidak ekonomis. Perlakuan hormon tanaman unggul memberikan pengaruh yang nyata terhadap pengamatan jumlah buah sisa setelah dilakukan analisa sidik ragam dan

Tabel 6. Rerata Jumlah Buah Sisa Tanaman Cabai yang Tidak Ekonomis dengan Perlakuan MOL Nasi dan Hormon Tanaman Unggul (buah)

\begin{tabular}{|c|c|c|c|c|c|}
\hline \multirow{2}{*}{$\begin{array}{l}\text { Faktor M (cc/l } \\
\text { air) } \\
\end{array}$} & \multicolumn{4}{|c|}{ Faktor H (cc/l air) } & \multirow{2}{*}{ Rerata } \\
\hline & H0 (0) & H1 (1) & H2 (2) & H3 (3) & \\
\hline M0 (0) & 65,67 & 77,67 & 91,50 & 79,50 & 78,58 \\
\hline M1 (50) & 78,50 & 80,83 & 84,67 & 82,67 & 81,67 \\
\hline M2 (100) & 80,67 & 81,00 & 91,33 & 89,50 & 85,63 \\
\hline M3 (150) & 77,83 & 78,33 & 89,17 & 78,33 & 80,92 \\
\hline \multirow[t]{2}{*}{ Rerata } & $75,67 \mathrm{~b}$ & $79,46 \mathrm{~b}$ & $89,17 \mathrm{a}$ & $82,50 \mathrm{~b}$ & \\
\hline & $\mathrm{KK}=$ & & & $\mathrm{BNJ} \mathrm{H}=7,77$ & \\
\hline
\end{tabular}


uji lanjut BNJ pada taraf 5\%.

Data pada Tabel 6 menunjukkan bahwa secara interaksi pemberian perlakuan MOL nasi dan hormon tanaman unggul tidak memberikan pengaruh yang nyata terhadap pengamatan jumlah buah sisa tanaman cabai yang tidak ekonomis. Namun, secara tunggal pemberian hormon tanaman unggul memberikan pengaruh yang nyata terhadap pengamatan jumlah buah sisa tanaman cabai yang tidak ekonomis.

Perlakuan H2 (2 cc/l air) merupakan perlakuan terbaik dengan jumlah buah sisa yang tidak ekonomis 89,17 buah. Menurut Jimmy (2011), hormon tanaman unggul ini mengandung zat pengatur tumbuh terutama Auksin, Gibberellin, Kinetin, Zeatin dan Sitokinin yang diformulasikan dari bahan alami yang dibutuhkan untuk semua jenis tanaman dengan kadar $\mathrm{GA}_{3}$ 98,37 ppm, $\mathrm{GA}_{5}$ 107,13 ppm, $\mathrm{GA}_{7} 131,46$ ppm, Auksin IAA 156,135 ppm dan Sitokinin (Kinetin 128,04 ppm dan Zeatin 106,45 ppm) dan kandungan pupuk N, P, Na, $\mathrm{Mg}, \mathrm{Cu}, \mathrm{Fe}, \mathrm{Mn}, \mathrm{Zn}, \mathrm{Co}, \mathrm{Cd}$ dan $\mathrm{Pb}$.

\section{KESIMPULAN}

Berdasarkan hasil penelitian yang telah dilakukan dapat diambil kesimpulan sebagai berikut:

1. Perlakuan MOL nasi dan hormon tanaman unggul secara interaksi memberikan pengaruh yang nyata terhadap pengamatan umur berbunga dan umur panen pertama dengan perlakuan terbaik M2H2 (MOL nasi $100 \mathrm{cc} / \mathrm{l}$ air + hormon tanaman unggul $2 \mathrm{cc} / \mathrm{l}$ air).

2. Perlakuan MOL nasi secara tunggal memberikan pengaruh yang nyata terhadap parameter pengamatan umur berbunga, umur panen pertama, berat buah per tanaman yang ekonomis dan berat buah per plot yang ekonomis dengan perlakuan terbaik M2 (MOL nasi $100 \mathrm{cc} / \mathrm{l}$ air).

3. Perlakuan hormon tanaman unggul secara tunggal memberikan pengaruh nyata terhadap pengamatan tinggi tanaman, umur berbunga, umur panen pertama, berat buah per tanaman yang ekonomis, berat buah per plot yang ekonomis dan jumlah buah sisa per tanaman yang tidak ekonomis dengan perlakuan terbaik $\mathrm{H} 2$ (hormon tanaman unggul $2 \mathrm{cc} / \mathrm{l}$ air).

\section{DAFTAR PUSTAKA}

Agromedia. 2008. Panduan Lengkap Budidaya dan Bisnis Cabai. Agromedia Pustaka. Jakarta.

Anonim. 2008. Hormon Tanaman Unggul. Didapat dari http://pupukhantu.wordpress.com/komposisil. Diakses pada tanggal 10 Juni 2013. Hormon Tanaman Unggul Multiguna. Online pada: http://pupukhantumultiguna.blogspot.com /2012/01/hormon-tanaman-unggul-multi guna.html. Diakses pada tanggal 12 Juni 2013.

Badan Pusat Statistik dan Direktorat Jenderal Hortikultura. 2010. Produksi Cabe Besar Menurut Provinsi. Online pada: http://www.deptan.go.id/infoeksekutif/hor ti/eis-horti/Produksi\%20Cabe

\%20Besar.pdf. Di akses pada tanggal 20 Maret 2012.

Ikhsan, M. 2012. Pengaruh Pemberian Pupuk Bokashi dan Hormon Tanaman Unggul Terhadap Pertumbuhan dan Produksi Cabai (Capsicum annum L.). Fakultas Pertanian Universitas Islam Riau. Pekanbaru.

Jimmy. 2011. Hormon Tanaman Unggul Multiguna Eksklusif. Online pada: www.jimmyhantu.com. Diakses pada tanggal 18 Maret 2012.

Purwasasmita, M. 2009. Mengenal SRI (Sistem of Rice Intensification). Online pada: http://sukatani-banguntani.blogspot.com. Diakses pada tanggal 11 Juni 2013.

Soverda, N dan Hermawati, T. 2009. Respon Tanaman Kedelai (Glycine max (L.) Merill) Terhadap Pemberian Berbagai Konsentrasi Pupuk Hayati. Fakultas Pertanian Universitas Jambi. Jurnal Agronomi, 13(1):

Zuprianto. 2012. Produksi Cabe Riau Belum Cukup Penuhi Permintaan. Online pada: http://riaubisnis.com/index.php/agricultur e-mainmenu-109/42 pertanian/2434produksi-cabe-riau-belum-cukup-penuhipermintaan? tmpl=component $\&$ print $=1 \&$ page. Diakses pada Tanggal 22 Maret 2012. 
